\title{
Plyometrics Exercise Effects Vollyball Athlete Smash Ability
}

\author{
Alex Aldha Yudi ${ }^{*}$ and Dimas Anggara ${ }^{2}$ \\ 1,2Dep. of Coaching, Faculty of Sport Science, Universitas Negeri Padang, Padang, Indonesia \\ *Corresponding author. Email: alexaldha@fik.unp.ac.id
}

\begin{abstract}
The problem in this study is the low ability to smash the volleyball athletes at the Guntur 1000 Kota Padang club. This study aims to determine the effect of plyometric training on improving the smash ability of the volleyball athletes at the Guntur 1000 Kota Padang club.The research design used was quasi-experimental research with one grouppree test-post test design. The study population was the volleyball athletes of the Guntur 1000 Kota Padang club, totaling 25 people consisting of 18 sons and 7 daughters. Sampling was done by purposive sampling, amounting to 12 male athletes. To measure the ability of the smash the smash ability test is used.Data analysis techniques using the data normality test and t-test. Results: There was a significant effect of plyometric training on the smash ability of the volleyball athletes of the Guntur 1000 Padang City club, where tcount $=3.78>$ ttable $=1.78$. The average volleyball smash ability in the initial test (4.75) category is lacking and the average volleyball smash ability in the final test (8.08) category is sufficient.
\end{abstract}

Keywords: Plyometric exercises and volleyball smash abilities

\section{INTRODUCTION}

Indonesia is a developing country which is in full swing implement development in all fields. One area that is not less important is the development in the field of sport. Sports now has progressed very rapidly. Where the sport has entered all aspects of life such as industry, economy, education and so forth.

To achieve maximum performance in the sport of volleyball, physical condition ready for exercise plays an important role, because any exercise program made should always include some aspects such as: physical, technical, tactical and psychological factors athlete. This is the basic factor performance of an athlete who connect with each other to achieve the feat.

One branch of achievement sport is volleyball, which is one of the sport popular and demand by people in Indonesia. The popularity of volleyball in the community as evidenced by the often held championships between clubs in Indonesia. The championship organized volleyball player aiming to build a reliable and potential to be a team that would be able to scent the region in national and international championships.

Someone to excel in the sport of volleyball they have to master the techniques that exist in the game of volleyball. According to Yunus (1992), "a technique in volleyball game play is defined as a way to efficiently and effectively in accordance with the applicable rules of the game in order to achieve an optimal result".

According Erianti, (2004) explains that:

"To be able to smash well in a volleyball game, an athlete must be supported by elements of technique, ability to cooperate dengantim, mental maturity, cohesiveness, experience and more importance should have a level of good physical condition, such as a power leg (explosive power leg muscles), so he was able to jump high to hit the ball over the net. "

Many sports that require explosive power, such as volleyball branch. Bafirman and Agus (2008) explains that, "the explosive power is the ability to direct the power quickly in a short time to provide the most good momentum on the body or an object in a movement intact eksplosive achieve the desired goal" .Daya explosive leg muscles is one one aspect of the basic components of physical condition is very important in sports volleyball, such as making a smash.

Ability smash done by giving the distance change height of the jump by maximizing the power of the explosive power leg muscle, one form of exercise that can be applied to maximize the height of the jump that exercise plyometrics, because exercise plyometrics aim to maximize the power of the explosive power leg muscle so it will be able to make the leap smash well, a volleyball player will easily smash if it has a maximum height of the jump and leg muscle explosive power was 
good, with at terapkannya plyometrik form of exercise is expected to be better athletes at the time of the smash.

Clubs son THUNDER 1000 is one of the volleyball clubs in the area of Padang. Clubs son Guntur 1000 was no outlet for their talents, interests as well as to deepen their skills in playing volleyball. THUNDER Club members in 1000 comprised students FIK UNP. In 1000 the club THUNDER facility and infrastructure that can support the process of exercise, such as: field, ball and some coaches from Nikken graduate UNP. It is expected that after the exercise of these players can play volleyball with good technique and most importantly which they may excel in volleyball.

Once the researchers conducted field observations, it turns out the son of club achievement Padang THUNDER 1000 can be said to be still low. It dapatdilihat Championship between clubs in Kuranji Padang police station on March 16, 2019, Thunder teams faced each other in 1000 against the Bank Nagari Padang, in a match which Guntur 1000 defeated by a score of 3-0. In this game the researchers see that very low ability to attack Guntur 1000 volleyball athlete, exercise programs in the first set of 16 points researchers saw no wasted because not smash over the net / out and only 9 poinsmash successful in doing well. Guntur club's poor performance in 1000 the son was allegedly one reason is the strength of his smash still lacking, because the ball is dismash often over the net, easily blocked by the opponent and often out of the field. It didugafaktor that influence is researchers saw that very low ability to smash, exercise programs, physical condition, training methods, still lower limb muscle explosive power volleyball player's Club Son of Thunder 1000.

As it is known, that the game of volleyball is a sport that is popular with the public in the world, both as a sport game and school sports and recreation. The basic idea of the game of volleyball is stricken opponent missed the ball through the top of the net and tried to turn off the opponent's ball area.

Initially the purpose of people playing volleyball in general to seek pleasure, as a positive rekeasi in their spare time. Then evolved towards other goals like wanting to improve physical fitness and health and aspires to become a high achieving volleyball player.

National level volleyball match was first held in PON II in Jakarta. Indonesian volleyball organization was formed on the initiative of the Association of volleyball Surabaya (IBVOS) and the Association of Volleyball Indonesia Jakarta (PERVID). On January 22, 1955, figures compiled volleyball convene the board and organization Ikada volleyball Indonesia at the Stadium. The meeting resulted in the decision, namely the formation of a national organization with the name volleyball volleyball All-Indonesian Association (PBVSI).

According Budayasa, (2014) "volleyball is a sport that is played in two teams in the field are separated by a net." According to Syaffrudin, (2004), "volleyball is a sport game that takes practice purposeful and systematic factors such as physical condition, technique, tactics and mentally ". Cooperation to four of these factors determines the accomplishment or the ability to match fisik.Persiapan especially physical condition is very important in practice to achieve high performance.

Based on the above quote, it can be concluded that in the game of volleyball to obtain figures or to obtain victory in various ways or techniques to do is include the smash technique. Therefore it is important for an athlete to master the technique smash volleyball or able to smash to the right target. Then this game involves almost all forms of movement that are jumping, punching and backed by physical elements such as leg muscle explosive power and muscular arms, leg muscle strength, coordination eye-tangan.Menurut Setiawan, Imam Sodikoen, and Sayuti Sahara (2017) "Muscle leg strength is the maximum force of contraction produced by a group of muscles. "which means that leg muscle strength is the maximum force generated by the contraction of muscle groups.

Smash in the game of volleyball is one technique, according Syafruddin (2011) "hitting techniques (spike) the ball in the game of volleyball is how a person or volleyball athletes hit the ball hard and focused to the defense of the opponent" .Next menurutFirdaus and Taufiq Hidayat (2014 ), smash a major blow during the attack to achieve victory. In the smash required a high jumping ability so that success can be achieved with a resounding ".According Suarsana, (2013)" smash is a major blow during the attack to achieve victory ". Similar expressed by Ridho and Alex Aldha Yudi (2019) that smash the labor movement foremost in the attack functions to drop the ball in the opposite field used against opponents defend the region from attack and make points or numbers. Guided by some opinions on the definition of smash in volleyball game that has been stated above, it is clear that smash a major blow in attack to score or points to earn the victory.

In performing the smash hit can be done several types based on the type of bait. Various smash by (Erianti, 2004) forms the feed as follows: "normal 1.Smash (opensmash) 2.Smash semi street. 3. Smash (push). 4. Smash pull. 5. Smash pull road. 6. Smash pull straight. 7. Smash cekis (drive smash). 8. Smash directly. 9. Smash from behind."

The process of implementing the following smashsebagai: Prefix stand with a normal attitude with a 
distance of 3 to 4 meters of net. At the time of going to hold a first step towards doing small steps in tempat.Tolakan small step forward, then rested with both legs accompanied by degrading motion body by bending the knees. Both arms was beside-back of the body followed by repulsion leg up explosively and assisted with the second swing arm from the back to the front-atas.Sikap when perkenaan perkenaan ball is at hand with a whipping motion, both arms and hands , The results will be more perfect blow when the whip hand and arm movement also followed membungkuk.Sikap end after the ball had struck, then smashser soon landed back on the ground.

Smashis a form of attack that is most widely used for the attack in an attempt to obtain the value of a team in a game of volleyball. Of some kind of smash at the top, so in this study was only conducted normal smash (smash open). That is how to play the ball efficiently and effectively in accordance with the rules of the game to reach the hard knocks that are usually lethal to the opponent by using normal smash (smash open).

To require physical and technical conditions are good, it is necessary to exercise. "Exercise is an activity or physical activity that is done repeatedly with the aim to improve certain physical or motor skills" (Irrawaddy, 2011). Exercise according Harsono in Idris, (2015) is a systematic process of training or work. In the game of volleyball smash technique there is an element of physical kodisi one of them is the explosive power (power) muscle, then the explosive power needed to be trained in order to increase the ability possessed by the athletes smash.

\section{a. Explosive Power Training Function}

According to Irrawaddy, (2017) One of the values of success in sport is measured by how much a person can throw, jump and other. Ability reject this is a manifestation of muscle explosive power seseorang.Agar one can jump as high as high, it takes a strong and quick repulsion of muscle leg muscles in addition to the swing arm. This capability is in need in some sports such as volleyball (when jumping unyuk smash).

According Masrun, (2016) that many training methods that can be used to increase power, one such method is plyometrics. Plyometrics exercises consist of several forms, depending on the objectives to dicapai.Menurut Adhi, et al, (2017) "plyometrics are exercises or repeat aimed at linking movement speed and power to produce explosive movements." This term is often used in linking movement repetitive jumping or stretch reflex exercise to produce an explosive reaction. MenurutBroto, (2015) says that plyometrics exercises are exercises that allow the muscles to reach maximum force in the shortest time possible.
Plyometrics can be considered a fast muscle fibers and nerves that turn on them, including various jumping exercises -lompat and by creating a plyometrics program by choosing the proper training and development intensity. Assuming all plyometrics exercises done optimally. Plyometrics principle burdens involved muscles.

Plyometrics an exercise that has a particular characteristic, namely a very strong muscle contraction is a response to dynamic loading or rapid strain of the muscles involved. Most of the muscles involved is because the leg muscles and pelvic muscle groups for real powerbase of the sport movement and actually have a major involvement in all movements. Method plyometrics exercises can improve muscle explosive power by using a combination of strength and speed of a sudden before the muscles to contract back or an exercise that allows the muscles to reach maximum force in the shortest time possible. So it can be concluded that plyometrics exercises have a significant role and benefits in

Form of plyometrics exercises were applied, namely Hurdle Hops and Knee-Tuck Jump. According Sudarmanto, et al (2018) argue about:

"HurdleHops a form of exercise that uses some of the obstacles that can be adjusted are made of wood or pipe, if the obstacle is not available low stools or cones can be used to replace and obstacles bias is formed like a bowl or cone (cone) are arranged uniformly and in the given distance shuttle hurdle hurdles .ketinggian can vary from $30-120 \mathrm{~cm}$, the number of hurdles when jumping low hurdles bias 8-10, 8-15 tall hurdles.

Movement begins with facing obstacles standing with feet hip-width apart and hands at his sides. Then execution refuse or jump to the first obstacle, immediately after landing, jump over the second hurdle and continue this movement until smua obstacle has been passed. This movement is done as quickly as possible while maintaining the width of the feet hipwidth apart at every hurdle.

According Harimbawa, et al (2014), knee-tuck jumps performed on a flat surface. This exercise is performed in a series of explosive fast stepping. According to Nugroho, et al (2013) "Exercise Kneetuck Jump is one form of exercise for developing vertical forces that are developing leg muscle strength and abdominal muscles in lifting heavy point loads. "Knee-tuck jump is one form of leg muscle strength training, how to implement it starting a standing position, then jump up quickly. Movement of the knee to the top quickly. Movement of the knee to the upper chest and try to touch the palm of the hand. 


\section{RESEARCH METHODS}

This study is a quasi-experimental research. The study was conducted at the club Thunder 1000 Padanggrouppree one design with test-post test, The population in this study amounted to 19 people (12 men and 7 athletes female athlete) .Next sample amounted to 12 people with a sampling technique that ispurposive sampling, Determine the sample with certain considerations in view can provide data to the fullest. As the independent variable in this study is a plyometrics workout and teriakatnya variable is the ability to smash volleyball.

Data collection techniques performed on the sample using the test's ability to measure the ability of volleyball smash smash volleyball athlete with the initial test (Pree-test) and final test (post-test). The data analysis technique used is using t-test or test meets the requirements of the assumptions made bedamean.Untuk normality test aims to determine whether the data obtained normal distribution or not.

\section{RESULTS AND DISCUSSION}

\section{1). Pree-Test Smash ability volleyball}

Pree-testkemampuan of the results obtained smash volleyball minimum value of 1 , the maximum value 10.Distribusi score produces an average (mean) of 4.75 and standard deviation is 2.83. The distribution of the complete data can be seen in the following table:

Table 1. Pree-Test Frequency Distribution Capabilities Smash volleyball

\begin{tabular}{|c|c|c|c|}
\hline \multirow{2}{*}{ Norma Ratings } & \multicolumn{2}{|c|}{ Frequency } & \multirow{2}{*}{ Category } \\
\cline { 2 - 3 } & Absolute & Relatively & \\
\hline$<4.42$ & 6 & 50 & Less than Once \\
\hline 4.44 to 6.87 & 3 & 25 & Less \\
\hline 6.88 to 9.30 & 2 & 17 & Enough \\
\hline 9.32 to 11.73 & 1 & 8 & Well \\
\hline$>11.75$ & 0 & 0 & Very well \\
\hline amount & 12 & 100 & \\
\hline
\end{tabular}

ranged from 6.88 to 9.30 belong to the category of

Based on the calculations shown in Table above from12 samples, $6(50 \%)$ obtained scores ranging between $<4.42$ belong to the category of less than once, 3 (25\%) obtained scores ranged from 4.44 to 6.87 belonging to the poor category, 2 (17\%) obtained scores pretty,1 people $(8 \%)$ obtained scores ranged from 9.32 to 11.73 belong in both categories, while both categories is absolutely no $(0 \%)$ which is owned by the son of club volleyball athletes Thunder 1000 Padang. For more details can also be found on the following histogramdi.

\section{Pree-Test Kemampuan Smash Bolavoli}

Frekuensi absolut $\quad$ Frekuensi relatif

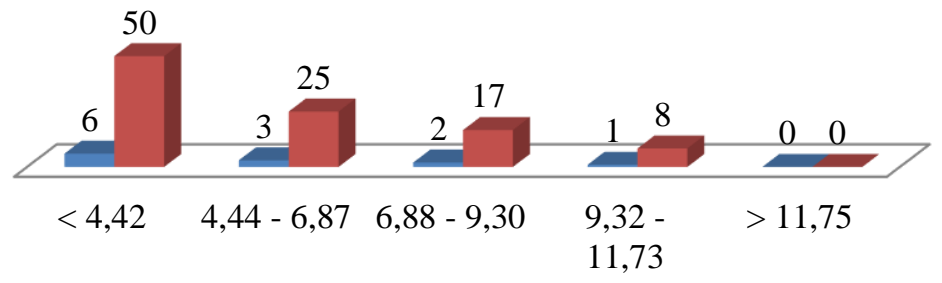

\section{Picture 1.Histogram Pree-TestKemampuan Smash volleyball Men's Athletes}

\section{2). Post-Test Smash ability volleyball \\ From the results of post-testkemampuan} volleyball smash obtained a value of at least 5, maximum value 13.Distribusi score produces an average (mean) of 8.08 and standard deviation is 2.43.The distribution of the complete data can be seen in the 
Table 2. Frequency Distribution of Post-Test Capability Smash volleyball

\begin{tabular}{|c|c|c|c|}
\hline \multirow{2}{*}{ Norma ratings } & \multicolumn{2}{|c|}{ Frequency } & \multirow{2}{*}{ category } \\
\cline { 2 - 3 } & absolute & relatively & \\
\hline$<4.42$ & 0 & 0 & Less than Once \\
\hline 4.44 to 6.87 & 4 & 33 & Less \\
\hline 6.88 to 9.30 & 4 & 33 & Enough \\
\hline 9.32 to 11.73 & 3 & 25 & Well \\
\hline$>11.75$ & 1 & 8 & Very well \\
\hline amount & 12 & 100 & \\
\hline
\end{tabular}

Contained in Table 2, it can be briefed as follows.From12 samples, 4 33\%) obtained scores ranged from 4.44 to 6.87 belong to the category of less, $4(33 \%)$ obtained scores ranged from 6.88 to 9.30 belong to the category of pretty, 3 (25\%) obtained scores ranged from 9.32 to 11.73 classified in either category, 1 people (8\%) obtained scores ranging between $>11,75$ tergolong in both categories once, while in the category of less absolutely no $(0 \%)$ which is owned by the son of club volleyball athletes Thunder 1000 Padang. For more details can also be found on the following histogram.

\section{Post-Test Kemampuan Smash Bolavoli}

- Frekuensi absolut $\quad$ Frekuensi relatif

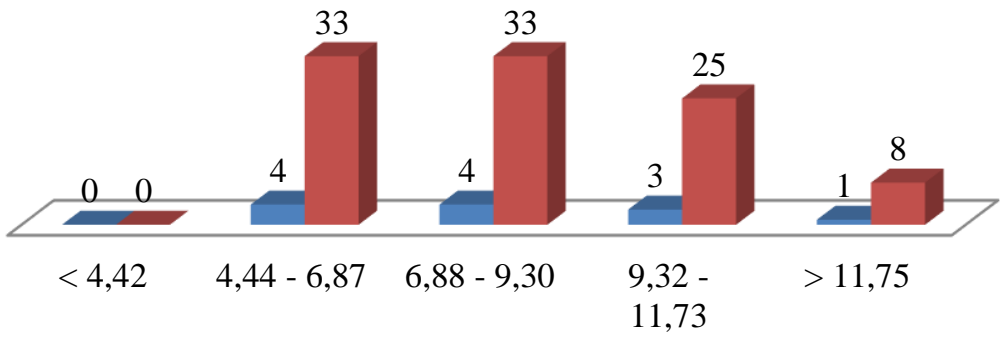

Figure 2.Post-Test Capability Histogram SmashAtlet volleyball Men

Testing Requirements Analysis

\section{Normality Test Data}

Normality test data using ujilillieforsdengan significance level $\alpha=0.05$ for $n=12$. The test criteria
L0 < Lt then the samples come from a normally distributed population. The results of the analysis of data normality test is presented in the table below:

Table 3. Normality Test volleyball Men's Athletes

\begin{tabular}{|c|c|c|c|}
\hline Group & Lo & Lt & information \\
\hline Pree-test & 0.149 & 0,242 & Normal \\
\hline Post-test & 0,139 & & \\
\hline
\end{tabular}

Based on normality test results both study groups previous pageLhitung obtained price obtained is smaller than Ltabel.Dengan Thus it can be argued that all groups of data in this study were taken from normally distributed population, so it can be used to test the hypothesis.

\section{Hypothesis Testing}

After the requirements analysis tested and found all variable data meets the requirements for testing the hypothesis. The statistical test used was t-test with a significant level of influence latihanpliometrik 0,05.Terdapat to increase the ability of volleyball club smashatlet Thunder 1000 Padang, with an average score of 4.75 and a standard deviation of 2.83 on a pre-test, 
and after perlakauan given 16 times, earned an average score of 8.08 and a standard deviation of 2.43 on a post- test.

Table 4. Hypothesis Testing Results

\begin{tabular}{|c|c|c|c|c|c|c|}
\hline $\begin{array}{c}\text { plyometrics } \\
\text { exercises }\end{array}$ & mean & SD & t & ttabel & Test results & ket \\
\hline Pre-test & 4.75 & 2.83 & & & & \\
\hline Post-test & 8.08 & 2.43 & & 1.78 & Significant & ha accepted \\
\hline
\end{tabular}

Based on the above table it can be said that there are significant latihanpliometrik to increase the ability of volleyball club smashatlet Thunder 1000 Padang $(\mathrm{t}=$ $3.78>$ ttabel $=1.78$ ), So the hypothesis is accepted.

Based on the analysis hypothesis test obtained hargathitung (3.78)> t table (1.78) at significance level $\alpha=0.05$. Thus, it can be concluded that Ho is rejected and $\mathrm{Ha}$ accepted. Thus there is significant influence from latihanpliometrik to improving the ability of volleyball club smashatlet Thunder 1000 Padang.

In doing plyometrics exercises on an ongoing basis in accordance with the training program has been prepared and adjusted it can improve the ability of volleyball club smasha tlet Thunder 1000 Padang. Useful for enhancing the ability of a good smash and the maximum that can produce poin.Kemampuan smash is in the book Great Indonesian Dictionary capability, which means the ability could be interpreted in movement while understanding the smash by $\mathrm{M}$. Marianto (2006) is "a strong blow where hand in full contact with the ball at the top, so the ball steep road at high speed, when hitting the ball higher above the net, the ball can be hit sharply downward.

From the above opinion at the time to produce the smash hit hard and jump high, it is necessary to exercise that had been arranged systematically and continuously, one form of exercise in improving the ability of the smash is plyometrics exercises. In addition, students must also have a strong motivation in itself in following the training process, because according Syafruddin (2012) "can be interpreted boost motivation or spirit within oneself to successfully do a job".

\section{CONCLUSIONS AND SUGGESTIONS}

\section{A. Conclusions}

Based on the research that has been described can be expressed as the following conclusion: There is pengaruhdari plyometrics exercises on the ability of men's club volleyball athletes smash Thunder 1000 Padang. Application of plyometrics exercises can improve volleyball smash.

\section{REFERENCES}

[1] Adhi, Bayu Purwo, et al. (2017). "Effect of Explosive Power Training Methods and limb muscle against muscle Power Limbs". Journal of Physical Education and Sports. Vol VI. No. 1, April 2017.

[2] Budayasa, et al. (2014). "The implementation of STAD Cooperative Learning to Improve Learning Activities and Results of Basic Technique volleyball Passing Over" .e-JournalPendidkan Health Physical Education and Recreation University of Ganesha. Vol I. No. 1, July 2014.

[3] Broto, Danang Pujo. (2015). "Effect of Exercise Pliometrics against Limb Muscle Power of Youth Athletes volleyball". Journal Motion. Vol VI. No. 2, September 2015. 174-185.

[4] Chu, Donald A. 1992. Jumping Into Plyometrics. IIIIionis: Leisure Pre

[5] Erianti. Festive 2004.Buku Bolavoli.FIK UNP

[6] Firdaus, Hidir \& Taufiq Hidayat. (2014). "Comparative Study Method Part (Part-Method) and Learning Methods Overall (Whole-Method) on the ability of students in the Doing Smash volleyball". Journal of Education and Health. Vol II. No. 2, July 2014. Page 363-369.

[7] Harimbawa, I Gst NYM, et al. (2014). "Training Effect Knee Tuck Split Jump and Jump to Increased flexibility and Muscle Power Limbs". eJournal IKOR Ganesha Education University. Vol. I, in November 2014. 1-11.

[8] Idris, Moh. (2015). "Improve Student Skills Penjas volleyball with Exercise Method". Journal of 
Physical Education, Health and Sport. Vol II. No. 1, June 2015. Page 1-10.

[9] Irawady, Hendri. 2011. Physical And Measurement. Padang: UNP Press. 2017. Physical Condition and Measurement. Padang: UNP Press.

[11] Irwanto, Edi. 2017. "Effect of Reciprocal Method and Practice Drill Against volleyball Basic Skills Improvement Techniques". Journal of Physical Education. Vol 6 No 1, June. It 10-20.

[12] Marianto, M. 2006. "The Great Ball Game II volleyball". Jakarta: Ministry of Education and Culture.

[13] Masrun. 2016. "Effect of Exercise Plyometrics (Bar Twist) to the Power Sleeve". Journal of Sport Science. Vol 26. No. 31. July 2016. Page 74-87.

[14] Nugroho, Muhammad Budi, et al. (2013). "Effect of plyometrics exercises and Knee Tuck Jump Depth Jump toward Hard Results Athletes kick Junior Football Team" Ghezang "SIMO". Journal of Sport Sciences and Fitness. Vol II. No. 3, December 2013. Page 47-51.

[15]Ridho, and Alex Aldha Yudi. 2019. "The contribution of Explosive Muscle Power Limbs and flexibility against Kedeng Smash Ability Athletes sepaktakraw PSTK Kayutanam". Journal Patriot. VolII. No. 2. July 2019. Page 178-185.
[16] Setiawan, Yogi, Imam Sodikoen, and Sayuti Sahara. (2017). "The Contribution of Leg Muscle Strength and Balance Dinamyc Towards The Ability of Dollyo Chagi Kick". The Yogyakarta 1st International Seminar on Health, Physical Education and Sports Science. October 2017. Page 524-258.

[17] Suarsana, I Made \& Addriana Fur Baan. (2013). "Arm Muscle Strength Exercise Influence on Accuracy in Gaming Smash volleyball Club Sigma Hammer" .e-JournalTadulako Physical Education, Health and Recreation. Vol I. No 3, May 2013. Page 1-11.

[18] Sudarmanto, Eko, et al. (2018). "Differences Influence of Plyometric Training Methods Depth Jump and Hurdle Hopping on Limb Muscle Power Increased Pesilat Young Women On Holy Footprint Putera Muhammadiyah University Simo Boyolali 2018". Vol III. No. 2, Ocktober 2018. Page 60-68.

[19] Syafruddin. Ball Game 2004. Voli.Padang: UNP Press Padang.

[20]___. Ball Game 2011. Voli.Padang: UNP Press Padang.

[21]__ 2012. Coaching Science Olahraga.Padang: UNP Press Padang.

[22] Yunus, M. 1992. Olahraga volleyball options. Jakarta: Ministry of Culture Pendidikandan. 